\title{
The effect of potassium on the sodium requirements of growing steers with and without $\alpha$-tocopherol supplementation
}

\author{
BY J. G. MORRIS* AND R. J. W. GARTNER \\ Animal Research Institute, Yeerongpilly, Brisbane, Australia \\ (Received 13 February 1973-Accepted 22 March 1974)
}

\begin{abstract}
I. Hereford steers, housed in concreted yards and given demineralized water, were offered ad lib. a low-sodium $(0.07 \mathrm{~g} \mathrm{Na}$ and $4.5 \mathrm{~g}$ potassium $/ \mathrm{kg}$ ) basal diet of sorghum grain, urea and minerals, to which $0,1_{5}$ or $3 \circ \mathrm{g} \mathrm{K}$ as $\mathrm{KHCO}_{3} / \mathrm{kg}$ diet had been added. Mean daily intakes of $\mathrm{K}$ were 26,107 and $\mathrm{I} 68 \mathrm{~g} / \mathrm{steer}$ respectively.

2. The steers were given daily supplements of $0,3.25$ or $6.5 \circ \mathrm{g} \mathrm{Na}$ as $\mathrm{NaHCO}_{3} / \mathrm{steer}$, added to the food; mean daily intakes of $\mathrm{Na}$ (food plus supplemental $\mathrm{NaHCO}_{3}$ minus residues) were $0.4 \mathrm{I}, 3.06$ and $6.26 \mathrm{~g} / \mathrm{steer}$ respectively.

3. Rate of gain of body-weight was positively related to the rate of $\mathrm{Na}$ supplementation and negatively related to the $\mathrm{K}$ content of the diet, but there was no interaction between $\mathrm{Na}$ and $\mathrm{K}$ contents of the diet.

4. The $\mathrm{Na}: \mathrm{K}$ ratios for the parotid saliva from steers not given $\mathrm{Na}$ supplements was $0 \cdot 3$, whereas steers ingesting either 3.1 or $6.3 \mathrm{~g} \mathrm{Na} / \mathrm{d}$ had Na:K ratios of about $\mathrm{r} 2$. Increasing the amount of $\mathrm{K}$ in the diet had no consistent effect on the saliva $\mathrm{Na}: \mathrm{K}$ ratio. The $\mathrm{Na}: \mathrm{K}$ ratios for rumen fluid reflected changes in the saliva $\mathrm{Na}: \mathrm{K}$ ratio in response to $\mathrm{Na}$ supplements and were inversely related to the amount of $\mathrm{K}$ in the diet.

5. The width of the adrenal zona glomerulosa from steers receiving the basal diet, without $\mathrm{Na}$ supplements, was significantly greater than that from steers given the $\mathrm{Na}$ supplements, but it was not affected by the amount of $\mathrm{K}$ in the diet.

6. Both Na supplements and the diet containing $30 \mathrm{~g}$ added $\mathrm{K} / \mathrm{kg}$ significantly increased the $\mathrm{Na}: \mathrm{K}$ ratio of the plasma.

7. The addition of $200 \mathrm{mg} \mathrm{DL}-\alpha$-tocopheryl acetate/steer per $\mathrm{d}$ to the diet had no significant effects on the growth rate of the steers.

8. It was concluded that the $\mathrm{Na}$ requirement of steers for growth was not significantly affected by the amount of $\mathrm{K}$ in the diet up to $168 \mathrm{~g} / \mathrm{d}$.
\end{abstract}

There is inadequate information about the quantitative sodium requirements of cattle for growth. Morris \& Gartner (197I) reported that on the basis of rate of weight gain, saliva composition and adrenal histology, the $\mathrm{Na}$ requirement of steers given an all-grain diet was not greater than $3^{\cdot} \mathrm{I} / \mathrm{d}$. Because diets containing a high proportion of roughage may contain considerably greater amounts of potassium than all-grain diets, the application of this requirement to diets other than all-grain diets was questioned. In this experiment the effect of the $\mathrm{K}$ content of the diet on $\mathrm{Na}$ requirements for growth was studied. Steers were given an all-grain diet to which 0,15 or $3 \circ \mathrm{g} \mathrm{K} / \mathrm{kg}$ had been added and they received daily Na supplements of $0,3.25$ or $6.50 \mathrm{~g}$.

The vitamin $\mathrm{E}$ requirements of cattle for growth have not been well defined (Agricultural Research Council, 1965), therefore the effect of the addition of $200 \mathrm{mg}$ DL- $\alpha$-tocopheryl acetate/steer per $\mathrm{d}$ to the diet was determined.

* Present address: Department of Animal Science, University of California, Davis, California 95616, USA. 
Table $\mathrm{r}$. Composition ( $\mathrm{g} / \mathrm{kg}$ dry matter) of the basal sorghum-grain*-urea-mineral mixture, and of the oaten chaff used to accustom the steers to the all-grain diet

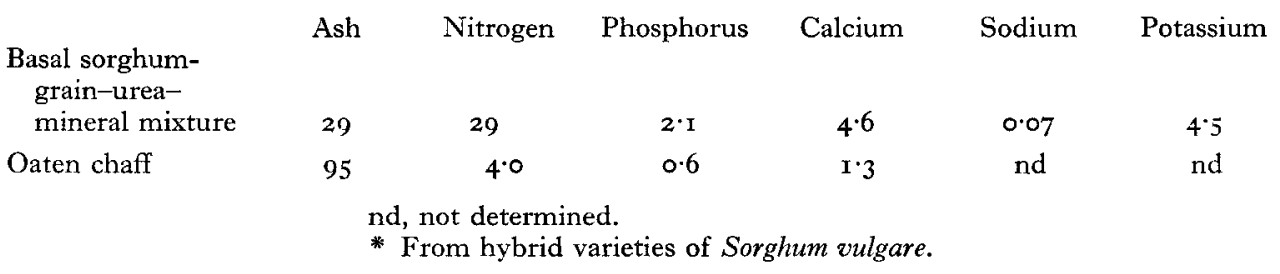

\section{EXPERIMEN'TAL}

\section{Animals}

Grade Hereford steers, about 12 months of age, were selected, on a beef cattle property in south-eastern Queensland, for uniformity of body-weight. They were transported to the Husbandry Research Farm, Rocklea, where they grazed pasture while they underwent the inoculations and passed the health tests described by Morris \& Pepper ( 1969 ). At the start of yard feeding, each steer was given orally $16 \mathrm{~g}$ thiabendazole (Thibenzole; Merck, Sharp \& Dohme (Australia) Pty Ltd, Granville, New South Wales) as an anthelminthic and $2.75 \mathrm{~g}$ retinyl palmitate (Rovimix A-325; Roche Products, Dee Why, New South Wales).

\section{Diet}

About $100 \mathrm{t}$ bulk grain from hybrid varieties of sorghum (Sorghum vulgare) were purchased from a local supplier. When required for feeding, it was prepared in $5 \mathrm{t}$ batches by coarse rolling using a mill set just to fracture the grain.

Three mixtures based on sorghum grain and containing $0,3^{8 \cdot 5}$ or $77 \mathrm{~g} \mathrm{KHCO}_{3} /$ $\mathrm{kg}$ were prepared. The $\mathrm{KHCO}_{3}$ in the mixture replaced an equal weight of sorghum grain. Each $\mathrm{Mg}$ mixture contained $20 \mathrm{~kg}$ urea and the following mineral mixture (kg): $7 \cdot 8$ calcium hydroxide, 4.5 commercial gypsum, $2 \cdot 0 \mathrm{NH}_{4} \mathrm{Cl}, 0 \cdot 100 \mathrm{MnSO}_{4} \cdot{ }_{4} \mathrm{H}_{2} \mathrm{O}$, $0.067 \mathrm{ZnSO}_{4} \cdot \mathrm{H}_{2} \mathrm{O}, 0.032 \mathrm{CuSO}_{4} \cdot{ }_{5} \mathrm{H}_{2} \mathrm{O}, 0.006 \mathrm{CoCl}_{2} \cdot 6 \mathrm{H}_{2} \mathrm{O}$. Before being added to the diet mixture, the minerals were made into an aqueous slurry and dried at $105^{\circ}$ to remove free ammonia. The resulting lumps were then ground to a powder and I $g$ potassium iodide was added.

Chaffed oaten stubble was used as a roughage to accustom the steers to the allgrain diet.

The proximate analyses of the basal sorghum-grain-urea-mineral mixture and of the oaten chaff are shown in Table $\mathbf{I}$.

\section{Design}

A $3 \times 3 \times 2$ factorial experiment was used to study the effect of the three rates of $\mathrm{Na}$ supplementation and the three amounts of $\mathrm{K}$ in the diet on the growth rate, food intake and $\mathrm{Na}$ and $\mathrm{K}$ metabolism of steers receiving two rates of $\alpha$-tocopherol supplementation. Sixty-three steers were randomly allocated as follows: fifty-four to the 
experimental treatments, resulting in three animals/treatment group, and nine to a pretreatment slaughter group to measure initial carcass weight.

The three rates of $\mathrm{Na}$ supplementation ( $\mathrm{g} \mathrm{Na}$ as $\mathrm{NaHCO}_{3} /$ steer per d) were: basal $(0.07 \mathrm{~g} \mathrm{Na} / \mathrm{kg}$ diet $)$, basal +3.25 , basal +6.50 ; the three amounts of $\mathrm{K}(\mathrm{g} / \mathrm{kg})$ in the diet were: basal $(4.5 \mathrm{~g} \mathrm{~K} / \mathrm{kg}$ diet $)$, basal + ${ }_{5}\left(38.5 \mathrm{~g} \mathrm{KHCO}_{3} / \mathrm{kg}\right)$, basal $+30(77 \mathrm{~g}$ $\mathrm{KHCO}_{3} / \mathrm{kg}$ ). The two rates of $\alpha$-tocopherol supplementation were $\circ$ and $200 \mathrm{mg}$ DL- $\alpha$-tocopheryl acetate as a stabilized powder (Rovimix E-25; Roche Products, Dee Why, New South Wales)/steer per d.

The pretreatment steers were slaughtered at the start of yard feeding. The remaining fifty-four steers were given the experimental rations for $126 \mathrm{~d}$ after which time they were slaughtered.

\section{Feeding schedule and yards}

For the first $6 \mathrm{~d}$ of yard feeding each of the eighteen groups of steers was offered a diet containing equal parts by weight of the grain diet and of roughage. The allocation of grain was gradually increased and that of roughage was progressively decreased until an all-grain diet was given $a d l i b$. on the 28 th day.

The yards had concreted floors and each group of three steers had a food trough $3.7 \mathrm{~m}$ in length. Until the $27^{\text {th }}$ day of yard feeding, water from the Brisbane city supply (about $0.04 \mathrm{~g} \mathrm{Na} / \mathrm{l}$ ) was given, thereafter demineralized water (less than $0.00 \mathrm{I} \mathrm{g}$ $\mathrm{Na} / \mathrm{l}$ ) was given ad lib.

Supplements of $\mathrm{NaHCO}_{3}$ and $\alpha$-tocopheryl acetate were added daily to the food trough for each group of steers, starting on the 28 th day of yard feeding.

\section{Measurements}

Body-weight and carcass-weight gain. The steers were weighed after being without food for $24 \mathrm{~h}$ and without water for $\mathrm{I} 2 \mathrm{~h}$ (fasted body-weight), both before entering the experiment and $24 \mathrm{~h}$ before slaughter. At weekly intervals body-weight was recorded without food or water restriction (non-fasted body-weight).

Carcass-weight gain was calculated as the difference between the final hot carcass weight and the product of the initial fasted body-weight and the mean dressing percentage of the pretreatment groups.

Food and water intake. Residues of uneaten food were removed at weekly intervals from the food troughs and weighed, and a representative sample was retained for analysis for $\mathrm{Na}$ and $\mathrm{K}$. The intake of water was measured daily for $\mathrm{I} 4 \mathrm{~d}$, from day $8 \mathrm{r}$ to day 93 of yard feeding.

Saliva. Samples of saliva were collected from each steer over a $2 \mathrm{~d}$ period immediately before the start of all-grain feeding and after $28,56,84$ and $9 \mathrm{I} d$ of all-grain feeding. The method of saliva collection has been described by Morris \& Gartner (I97I).

Blood, urine and rumen fluid. Samples of blood and urine were collected from the steers at the end of the 9Ist day of all-grain feeding ( $\mathrm{I}$ week before slaughter). Rumen fluid samples were obtained at slaughter. Samples of saliva, whole blood, plasma, urine and rumen fluid were analysed for $\mathrm{Na}$ and $\mathrm{K}$, the plasma samples were also analysed for chloride. 
Organs and glands. At slaughter the parotid salivary glands and adrenals were collected, weighed and prepared for histological examination as described by Morris \& Gartner (197r).

\section{Analytical methods}

The analytical methods used were those described by Morris \& Gartner (197x), except for the tocopherol content of the sorghum grain which were estimated by the method of Nobile ( 1963 , and personal communication). This method involved digestion of the milled grain with enzymes in water at $45^{\circ}$ in the presence of an antioxidant; treatment with ammonia and ethanol, and extraction with a diethyl ether-petroleum spirit (b.p. $40^{\circ}-60^{\circ}$ ). The extract was purified by saponification and extraction procedures, and one-dimensional, thin-layer chromatography using Kieselgel G (E. Merck AG, Darmstadt, West Germany) and fluorescein plates with chloroform as the developing solvent. The separate bands of $\alpha-, \beta-+\gamma-$ and $\delta$-tocopherols were removed from the plates and eluted with ethanol followed by diethyl ether. The amount of tocopherols was estimated from the colour developed by the addition of I, I'-bipyridyl and ferric chloride. Two-dimensional, thin-layer chromatography using chloroform as the developing solvent in the first dimension and di-isopropyl ether-petroleum spirit (b.p. $\left.40^{\circ}-60^{\circ}\right)(\mathrm{r}: 4, \mathrm{v} / \mathrm{v})$ in the second dimension, was used to check the purity of $\alpha$-tocopherol.

Results were analysed by analysis of variance. The effects were tested $v . \mathrm{Na}, \mathrm{K}$ and $\alpha$-tocopherol $\times$ animals as error, with the exception of food and water intake as the animals were group-fed. For the analysis of growth rate a linear regression $(y=$ $\mathrm{a}+\mathrm{b} x$ ) of body-weight $(y) v$. time $(x)$ was computed and the ' $\mathrm{b}$ ' values used in the analysis of variance.

\section{RESULTS}

Net intakes of $N a$ and $K$. The food residues from all steers contained a higher percentage of ash and $\mathrm{Na}$ than the basal diet, apparently the result of sedimentation of the mineral additives. The mean net daily intakes of $\mathrm{Na}$, calculated from the $\mathrm{Na}$ in the basal diet, $\mathrm{NaHCO}_{3}$ supplement, and residues, were $0.4 \mathrm{I}, 3 \cdot 06$ and $6.26 \mathrm{~g}$ for the three treatments: basal ( $0.07 \mathrm{~g} \mathrm{Na} / \mathrm{kg}$ ), basal +3.25 and $6.50 \mathrm{~g} \mathrm{Na} / \mathrm{d}$ respectively. The mean daily intakes of $\mathrm{K}$ for groups given 0 , 15 and $30 \mathrm{~g}$ added $\mathrm{K} / \mathrm{kg}$ diet, were 26 , 107 and I $68 \mathrm{~g} \mathrm{~K} /$ steer respectively.

Food and water intake. The mean daily food intake was greater for the steers receiving Na supplements $(6.4$ and $6.6 \mathrm{~kg}$ at intakes of $3 . \mathrm{I}$ and $6.3 \mathrm{~g} \mathrm{Na} / \mathrm{d}$ respectively) than for those given no Na supplement $(5 \cdot 7 \mathrm{~kg})$. These differences were significant $(P<0.0$ I $)$ when weeks $\times \mathrm{Na} \times \alpha$-tocopherol was used as error. However, the interaction of $\mathrm{Na} \times \mathrm{K} \times \alpha$-tocopherol was significant when tested $v . \mathrm{Na} \times \mathrm{K} \times \alpha$ tocopherol $\times$ weeks as error. When $\mathrm{Na} \times \mathrm{K} \times \alpha$-tocopherol was used as error, none of the treatments had a significant effect on food intake. As the steers were fed in groups, it was not possible to obtain a within-group measure of variance.

Similarly, treatments had no significant effect on water intake because the $\mathrm{Na} \times \mathrm{K} \times$ $\alpha$-tocopherol error term was large.

Body-weight changes. The initial and final fasted body-weights of the steers are 


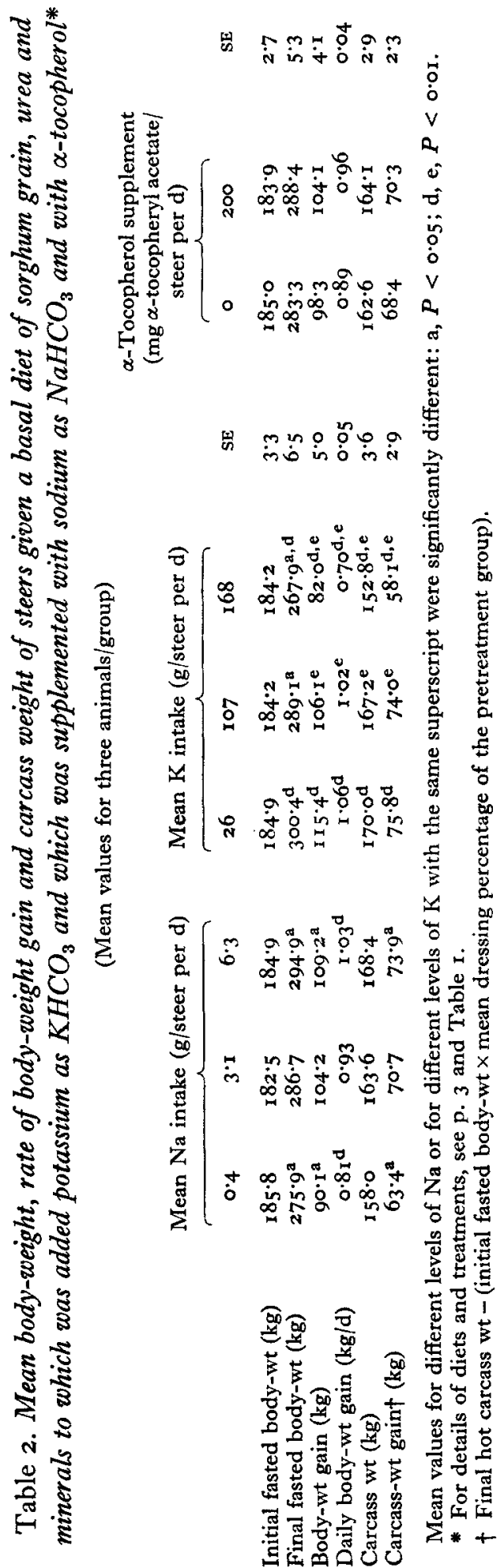


Table 3. Daily rate of body-weight gain $(\mathrm{kg} / \mathrm{d})$ for steers given a basal diet of sorghum grain, urea and minerals to which was added potassium as $\mathrm{KHCO}_{3}$ and which was supplemented with sodium as $\mathrm{NaHCO}_{3}{ }^{*}$

(Mean values for three animals/group for the period of all-grain feedingt)

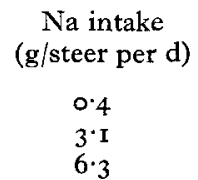

\begin{tabular}{|c|c|c|}
\hline \multicolumn{3}{|c|}{ Mean $\mathrm{K}$ intake ( $\mathrm{g} /$ steer per $\mathrm{d}$} \\
\hline 26 & 107 & I 68 \\
\hline 0.99 & $1 \cdot 12$ & 0.73 \\
\hline $1 \cdot 22$ & $I \cdot I 6$ & 0.67 \\
\hline $\mathrm{I} \cdot 27$ & $I \cdot r_{4}$ & 0.89 \\
\hline
\end{tabular}

Least significant difference: 0.26 for $P<0.05 ; 0.34$ for $P<0.0$.

* For details of diets and treatments, see p. 3 and Table $I$.

+ The animals were accustomed to an all-grain diet by giving decreasing amounts of roughage in a grain-roughage diet; for details, see p. 3 .

Table 4. Mean concentrations of sodium, potassium and $\mathrm{Na}+K$ (mmol/l) and the $\mathrm{Na}: \mathrm{K}$ ratio for saliva from steers given a basal diet of sorghum grain, urea and minerals to which was added $\mathrm{K}$ as $\mathrm{KHCO}_{3}$ and which was supplemented with $\mathrm{Na}$ as $\mathrm{NaHCO}_{3}{ }^{*}$

(Mean values for three animals/group)

\begin{tabular}{|c|c|c|c|c|c|c|c|c|}
\hline \multirow{2}{*}{$\begin{array}{l}\text { Period of all- } \\
\text { grain feeding } \dagger \\
\text { (d) }\end{array}$} & & \multicolumn{3}{|c|}{$\begin{array}{l}\text { Mean Na intake } \\
(\mathrm{g} / \text { steer per } \mathrm{d})\end{array}$} & \multicolumn{3}{|c|}{$\begin{array}{l}\text { Mean } \mathrm{K} \text { intake } \\
\text { (g/steer per } \mathrm{d} \text { ) }\end{array}$} & \multirow[b]{2}{*}{$\mathrm{SE}$} \\
\hline & & 0.4 & $3 \cdot 1$ & $6 \cdot 3$ & 26 & 107 & I 68 & \\
\hline 0 & $\begin{array}{l}\mathrm{Na} \\
\mathrm{K} \\
\mathrm{Na}+\mathrm{K} \\
\mathrm{Na}: \mathrm{K}\end{array}$ & $\begin{array}{c}116^{\mathrm{d}, \mathrm{f}} \\
8 \cdot 4^{\mathrm{d}, e} \\
124^{\mathrm{d}, \mathrm{e}} \\
15 \cdot 5^{\mathrm{d}, e}\end{array}$ & $\begin{array}{r}148^{\mathrm{d}, \mathrm{e}} \\
6 \cdot 2^{\mathrm{d}} \\
154^{\mathrm{d}, \mathrm{f}} \\
24^{\cdot} 8^{\mathrm{d}}\end{array}$ & $\begin{array}{r}129^{\mathrm{e}, \mathrm{f}} \\
5 \cdot 5^{\mathrm{e}} \\
135^{\mathrm{e}, \mathrm{f}} \\
24^{\circ} 9^{\mathrm{e}}\end{array}$ & $\begin{array}{r}134^{d} \\
6 \cdot 6 \\
14 I^{d} \\
22 \cdot 6\end{array}$ & $\begin{array}{c}134^{\mathrm{e}} \\
6 \cdot 7 \\
140^{\mathrm{e}} \\
22 \cdot 0\end{array}$ & $\begin{array}{c}124^{\mathrm{d}, \mathrm{e}} \\
6 \cdot 9 \\
13 \mathrm{I}^{\mathrm{d}, \mathrm{e}} \\
20^{\circ} \cdot 5\end{array}$ & $\begin{array}{l}2 \cdot 23 \\
0 \cdot 38 \\
2 \cdot 12 \\
1 \cdot 25\end{array}$ \\
\hline 28 & $\begin{array}{l}\mathrm{Na} \\
\mathrm{K} \\
\mathrm{Na}+\mathrm{K} \\
\mathrm{Na}: \mathrm{K}\end{array}$ & $\begin{array}{c}53^{\mathrm{d}, \mathrm{e}} \\
83^{\mathrm{d}} 3^{\mathrm{d}, \mathrm{e}} \\
135^{\mathrm{d}, \mathrm{e}} \\
0 \cdot 80^{\mathrm{d}, \mathrm{e}}\end{array}$ & $\begin{array}{l}\mathrm{I} 34^{\mathrm{d}} \\
\text { I } 3 \cdot \mathrm{I}^{\mathrm{d}} \\
\mathrm{I} 47^{\mathrm{d}} \\
\quad \mathrm{I} 3 \cdot \mathrm{I}^{\mathrm{a}, \mathrm{d}}\end{array}$ & $\begin{array}{l}140^{\mathrm{e}} \\
9.5^{\mathrm{e}} \\
150^{\mathrm{e}} \\
16 \cdot 0^{\mathrm{a}, \mathrm{e}}\end{array}$ & $\begin{array}{l}107 \\
36 \cdot 3^{2} \\
144 \\
I I \cdot 6^{a}\end{array}$ & $\begin{array}{l}\text { II } 5^{\mathrm{d}} \\
28 \cdot 9^{\mathrm{a}, \mathrm{d}} \\
\mathrm{I}_{4} \\
8 \cdot 3^{\mathrm{a}}\end{array}$ & $\begin{array}{l}\mathrm{IO}^{\mathrm{d}} \\
40^{\mathrm{d}} 7^{\mathrm{d}} \\
144^{.9}\end{array}$ & $\begin{array}{l}2 \cdot 85 \\
2 \cdot 56 \\
2 \cdot 04 \\
0 \cdot 93\end{array}$ \\
\hline $5^{6}$ & $\begin{array}{l}\mathrm{Na} \\
\mathrm{K} \\
\mathrm{Na}+\mathrm{K} \\
\mathrm{Na}: \mathrm{K}\end{array}$ & $\begin{array}{c}34^{\mathrm{d}, e} \\
96 \cdot 9^{\mathrm{d}, e} \\
13^{\mathrm{d}, e} \\
0 \cdot 3^{\mathrm{d}, e}\end{array}$ & $\begin{array}{l}\mathrm{r} 30^{\mathrm{d}} \\
18 \cdot 8^{\mathrm{d}} \\
\mathrm{I}_{49^{\mathrm{d}}} \\
\text { II. } 9^{\mathrm{d}}\end{array}$ & $\begin{array}{l}128^{\mathrm{e}} \\
14.9^{\mathrm{e}} \\
143^{\mathrm{e}} \\
10.9^{\mathrm{e}}\end{array}$ & $\begin{array}{c}97^{\mathrm{d}} \\
49^{\circ} 4^{\mathrm{a}} \\
\mathrm{I} 4^{\mathrm{d}} \\
\quad 7^{\circ} 6\end{array}$ & $\begin{array}{c}106 \\
39^{\cdot 2^{2}} \\
146^{\mathrm{e}} \\
9 \cdot 2\end{array}$ & $\begin{array}{c}89^{\mathrm{d}} \\
42 \cdot \mathrm{I} \\
13 \mathrm{I}^{\mathrm{d}, \mathrm{e}} \\
6 \cdot 3\end{array}$ & $\begin{array}{l}3 \cdot 66 \\
3 \cdot 16 \\
2 \cdot 43 \\
I \cdot 14\end{array}$ \\
\hline 84 & $\begin{array}{l}\mathrm{Na} \\
\mathrm{K} \\
\mathrm{Na}+\mathrm{K} \\
\mathrm{Na}: \mathrm{K}\end{array}$ & $\begin{array}{l}24^{\mathrm{d}, e} \\
105.0^{\mathrm{d}, e} \\
129^{\mathrm{d}, \mathrm{e}} \\
\quad 0.23^{\mathrm{d}, e}\end{array}$ & $\begin{array}{l}13^{6 d} \\
13 \cdot 4^{d} \\
149^{d} \\
11 \cdot 9^{d}\end{array}$ & $\begin{array}{l}135^{\mathrm{e}} \\
10.6^{\mathrm{e}} \\
146^{\mathrm{e}} \\
13.8^{\mathrm{e}}\end{array}$ & $\begin{array}{c}92^{\mathrm{a}, \mathrm{b}} \\
45^{\circ} 4 \\
\text { 工3 } 8 \\
8 \cdot 5\end{array}$ & $\begin{array}{l}102^{\mathrm{a}} \\
42 \cdot 0 \\
144 \\
9 \cdot \mathrm{I}\end{array}$ & $\begin{array}{c}100^{b} \\
41 \cdot 7 \\
142 \\
8 \cdot 3\end{array}$ & $\begin{array}{l}2 \cdot 58 \\
2 \cdot 60 \\
2 \cdot 75 \\
0.65\end{array}$ \\
\hline $9 \mathrm{I}$ & $\begin{array}{l}\mathrm{Na} \\
\mathrm{K} \\
\mathrm{Na}+\mathrm{K} \\
\mathrm{Na}: \mathrm{K}\end{array}$ & $\begin{array}{l}28^{\mathrm{d}, \mathrm{e}} \\
107^{-1} \mathrm{~d}, \mathrm{e} \\
135^{\mathrm{d}, \mathrm{e}} \\
0.27^{\mathrm{d}, \mathrm{e}}\end{array}$ & $\begin{array}{l}\mathrm{I} 34^{\mathrm{d}} \\
\mathrm{II} \cdot 9^{\mathrm{d}} \\
145^{\mathrm{d}} \\
\mathrm{I} 3 \cdot 0^{\mathrm{d}}\end{array}$ & $\begin{array}{l}\text { I } 37^{\mathrm{e}} \\
\text { I } 2 \cdot 7^{\mathrm{e}} \\
\text { I } 50^{\mathrm{e}} \\
\text { I } 2.8 \mathrm{e}\end{array}$ & $\begin{array}{c}102^{\mathrm{a}} \\
45^{\cdot 2} \\
147^{\mathrm{a}} \\
10 \cdot 1\end{array}$ & $\begin{array}{l}101 \\
42 \cdot 7 \\
144 \\
8 \cdot 2\end{array}$ & $\begin{array}{c}95^{\mathrm{a}} \\
43^{\cdot} \cdot 8 \\
139^{\mathrm{a}} \\
7 \cdot 8\end{array}$ & $\begin{array}{l}2 \cdot 17 \\
2.68 \\
2 \cdot 35 \\
0.92\end{array}$ \\
\hline
\end{tabular}

Mean values for different levels of $\mathrm{Na}$, or for different levels of $\mathrm{K}$ with the same superscript were significantly different: a, b, $P<0.05$; d, e, f, $P<0.01$.

* For details of diets and treatments, see p. 3 and Table $I$.

$\dagger$ The animals were accustomed to an all-grain diet by giving decreasing amounts of roughage in a grain-roughage diet; for details, see p. 3 . 
Table 5. Mean concentrations of sodium, potassium and $\mathrm{Na}+\mathrm{K}$ (mmol/l) and the $\mathrm{Na}: \mathrm{K}$ ratio for rumen fuid taken immediately before slaughter (9rst day) from steers given a basal diet of sorghum grain, urea and minerals to which was added $\mathrm{K}_{\text {as }} \mathrm{KHCO}_{3}$ and which was supplemented with $\mathrm{Na}$ as $\mathrm{NaHCO}_{3}{ }^{*}$

(Mean values for three animals/group)

\begin{tabular}{|c|c|c|c|c|c|c|c|}
\hline & \multicolumn{3}{|c|}{$\begin{array}{l}\text { Mean Na intake } \\
(\mathrm{g} / \text { steer per } \mathrm{d})\end{array}$} & \multicolumn{3}{|c|}{$\begin{array}{l}\text { Mean } K \text { intake } \\
\text { (g/steer per } d)\end{array}$} & \multirow[b]{2}{*}{ SE } \\
\hline & 0.4 & 31 & 6.3 & 26 & 107 & I 68 & \\
\hline $\begin{array}{l}\mathrm{Na} \\
\mathrm{K}\end{array}$ & $\begin{array}{r}33 \cdot 5^{\mathrm{d}, \mathrm{e}} \\
\mathrm{I} 20^{\circ} 3^{\mathrm{d}, \mathrm{e}}\end{array}$ & $\begin{array}{r}I I 4 \cdot 0^{d} \\
51 \cdot 5^{d}\end{array}$ & $\begin{array}{r}\operatorname{II2} \cdot 7^{\mathrm{e}} \\
55^{\circ} 3^{\mathrm{e}}\end{array}$ & $\begin{array}{c}101 \cdot 5^{d, e} \\
63 \cdot 1 d\end{array}$ & $\begin{array}{l}88 \cdot 7^{\mathrm{d}, \mathrm{f}} \\
68 \cdot 8^{\mathrm{e}}\end{array}$ & $\begin{array}{l}70 \cdot 0^{e, f} \\
90 \cdot I^{d, e}\end{array}$ & $\begin{array}{l}3 \cdot 3 \\
2 \cdot 8\end{array}$ \\
\hline $\begin{array}{l}\mathrm{Na}+\mathrm{K} \\
\mathrm{Na}: \mathrm{K}\end{array}$ & $\begin{array}{r}I 53.9^{\mathrm{d}, e} \\
0.3^{\mathrm{d}, e}\end{array}$ & $\begin{array}{r}165 \cdot 4^{d} \\
2 \cdot 6^{d}\end{array}$ & $\begin{array}{r}163.0^{e} \\
2.8^{e}\end{array}$ & $\begin{array}{r}164 \cdot 7^{\mathrm{a}} \\
2 \cdot 8^{\mathrm{d}, \mathrm{f}}\end{array}$ & $\begin{array}{l}\mathrm{I} 57^{\circ} 5^{\mathrm{a}} \\
\mathrm{I} \cdot 8^{\mathrm{d}}, \mathrm{f}\end{array}$ & $\begin{array}{l}I 60 \cdot I \\
I \cdot 0 e, f\end{array}$ & $\begin{array}{l}2.2 \\
0.12\end{array}$ \\
\hline
\end{tabular}

Mean values for different levels of $\mathrm{Na}$, or for different levels of $\mathrm{K}$ with the same superscript were significantly different: $\mathrm{a}, \mathrm{b}, P<0.05 ; \mathrm{d}, \mathrm{e}, \mathrm{f}, P<0.0 \mathrm{r}$.

* For details of diets and treatments, see p. 3 and Table $I$.

shown in Table 2. Supplements of $\mathrm{Na}$ increased total body-weight gains. The effect of $3.1 \mathrm{~g} \mathrm{Na} / \mathrm{d}$ was significant at $P<0.06$, whereas the effect of $6.3 \mathrm{~g} \mathrm{Na} / \mathrm{d}$ was significant at $P<0.02$. The addition of $\mathrm{KHCO}_{3}$ to the diet decreased the total bodyweight gain, the effect being most apparent in steers given the basal diet $+30 \mathrm{~g} \mathrm{~K} / \mathrm{kg}$. The effect of $\mathrm{NaHCO}_{3}$ and $\mathrm{KHCO}_{3}$ on the daily rate of body-weight gain for the period of all-grain feeding is shown in Table 3 . While there is no significant interaction between $\mathrm{NaHCO}_{3}$ and $\mathrm{KHCO}_{3}$ treatments, it appeared that the effect of $\mathrm{Na}$ supplements on total and daily body-weight gain was greater for steers given the basal diet than for those receiving diets containing added $\mathrm{KHCO}_{3}$.

$\alpha$-Tocopherol supplementation had no significant effect on total body-weight gain or daily rate of body-weight gain or any of the subsequent measurements.

Carcass-weight changes. The effects of the $\mathrm{Na}$ and $\mathrm{K}$ supplements on carcass weight and carcass-weight gain (Table 2) were similar to those recorded for body-weight gain. There was also no significant interaction between the $\mathrm{Na}$ and $\mathrm{K}$ treatments on carcass-weight gain or any of the other measurements.

Health of the steers. There was a positive relationship between the incidence of rumen tympany and the $\mathrm{KHCO}_{3}$ content of the diet. Over-distension of the rumen was not found in steers given the diet with no added $\mathrm{KHCO}_{3}$, whereas it was frequently found, particularly in the latter part of the experiment, in steers given the diets containing 38.5 and $77 \mathrm{~g} \mathrm{KHCO}_{3} / \mathrm{kg}$. Tympany was more severe in steers given the diet containing $77 \mathrm{~g} \mathrm{KHCO}_{3} / \mathrm{kg}$ than in those given the diet containing $38.5 \mathrm{~g}$ $\mathrm{KHCO}_{3} / \mathrm{kg}$. On four occasions one or more steers given the diet with $77 \mathrm{~g} \mathrm{KHCO}_{3} / \mathrm{kg}$ required treatment with anti-bloat oil. One steer given the diet containing $38.5 \mathrm{~g}$ $\mathrm{KHCO}_{3} / \mathrm{kg}$ died from primary rumen tympany 3 weeks before the end of the experiment.

Saliva. The concentration of $\mathrm{Na}$ in saliva from steers not given supplements of $\mathrm{NaHCO}_{3}$ decreased progressively during the period of all-grain feeding (Table 4) whereas the concentration of $\mathrm{K}$ progressively increased, resulting in a decrease in the 
Table 6. Mean concentrations of sodium and chloride ion (mmol/l) and the Na:potassium ratio for plasma taken immediately before slaughter (91st day) from steers given a basal diet of sorghum grain, urea and minerals to which was added $\mathrm{K}$ as $\mathrm{KHCO}_{3}$ and which was supplemented with $\mathrm{Na}$ as $\mathrm{NaHCO}_{3}{ }^{*}$

(Mean values for three animals/group)

\begin{tabular}{|c|c|c|c|}
\hline & & $\begin{array}{l}n \mathrm{Na} \text { int } \\
\text { teer per }\end{array}$ & \\
\hline & 0.4 & $3 \cdot I$ & $6 \cdot 3$ \\
\hline $\mathrm{Na}$ & $128 \cdot 2^{\mathrm{d}, e}$ & $13 x \cdot 7^{d}$ & $13 \mathrm{I} \cdot 8^{\mathrm{e}}$ \\
\hline $\mathbf{K}$ & $5 \cdot 3^{2, d}$ & $4 \cdot 8^{\mathrm{a}}$ & $4^{\cdot 6^{d}}$ \\
\hline $\begin{array}{l}\mathrm{Na}+\mathrm{K} \\
\mathrm{Na} \cdot \mathrm{K}\end{array}$ & $133.5^{\mathrm{d}, \mathrm{e}}$ & $\begin{array}{r}136 \cdot 6^{d} \\
27 \cdot 6 d\end{array}$ & $13^{6 \cdot 4^{e}}$ \\
\hline $\mathrm{Cl}$ & $101 \cdot 4^{d}$ & $103 \cdot 4^{a, d}$ & $102 \cdot 1^{a}$ \\
\hline
\end{tabular}

\begin{tabular}{|c|c|c|c|}
\hline \multicolumn{3}{|c|}{$\begin{array}{l}\text { Mean } K \text { intake } \\
\text { (g/steer per d) }\end{array}$} & \multirow[b]{2}{*}{ SE } \\
\hline 26 & 107 & I 68 & \\
\hline $129^{\circ} 0^{d}$ & $129^{6} 6^{\mathrm{e}}$ & $133^{.} 2^{\mathrm{d}, \mathrm{e}}$ & 0.51 \\
\hline $5^{\cdot 1^{a}}$ & 5.0 & $4^{\cdot 6^{a}}$ & 0.14 \\
\hline $134^{\cdot} \mathrm{I}^{\mathrm{d}}$ & $134^{\cdot 6} 6^{e}$ & I $37 \cdot 8^{\mathrm{d}, \mathrm{e}}$ & 0.54 \\
\hline $25 \cdot 4^{d}$ & $26 \cdot 7^{2}$ & $29^{\circ} 0^{a, d}$ & 0.75 \\
\hline $102 \cdot I$ & $10_{3} \cdot 2^{a}$ & $101 \cdot 7^{2}$ & 0.42 \\
\hline
\end{tabular}

Mean values for different levels of $\mathrm{Na}$, or for different levels of $\mathrm{K}$ with the same superscript were significantly different: a, $P<0.05$; d, e, $P<0.0$.

* For details of diets and treatments, see p. 3 and Table $\mathrm{r}$.

$\mathrm{Na}: \mathrm{K}$ ratio for the saliva. Neither $\mathrm{K}$ levels nor the interaction $\mathrm{Na} \times \mathrm{K}$ had a significant effect on the saliva $\mathrm{Na}: \mathrm{K}$ ratio. At each sampling period $\mathrm{Na}+\mathrm{K}$ content was less in the saliva from steers not given Na supplements than from those given the $\mathrm{Na}$ supplements. Although the differences between the composition of saliva from steers given diets with different $\mathrm{KHCO}_{3}$ contents were statistically significant for some days of the experiment, these differences did not show a consistent trend.

Rumen fluid. The concentration of $\mathrm{Na}$ in the rumen fluid taken immediately before slaughter (9rst day) from steers not receiving Na supplements was significantly less and the $\mathrm{K}$ concentration was significantly greater than that from steers receiving daily $\mathrm{Na}$ supplements (Table 5 ). Steers given diets with added $\mathrm{KHCO}_{3}$ ( 107 and $\mathrm{I} 68 \mathrm{~g} \mathrm{~K}$ ingested/d) had a significantly lower concentration of $\mathrm{Na}$ in their rumen fluid than those receiving the basal diet alone $(26 \mathrm{~g} \mathrm{~K}$ ingested/d). The $\mathrm{K}$ concentration in the rumen fluid from the steers ingesting $168 \mathrm{~g} \mathrm{~K} / \mathrm{d}$ was significantly greater than from those ingesting $26 \mathrm{~g} \mathrm{~K} / \mathrm{d}(P<0.01)$.

$\mathrm{Na}, \mathrm{K}$ and Cl concentrations for plasma and erythrocytes. The concentrations of $\mathrm{Na}$ and $\mathrm{K}$ in the samples of plasma taken immediately before slaughter ( $9 \mathrm{I} \mathrm{d}$ of all-grain feeding) (Table 6) indicated that in the plasma samples from steers given the basal diet without Na supplements there was a small but significant decrease in Na concentrations, and a similar significant increase in $\mathrm{K}$ concentrations. The highest level of $\mathrm{K}$ intake ( $168 \mathrm{~g} / \mathrm{d}$ ) resulted in a significant increase in plasma $\mathrm{Na}$ concentration and a decrease in plasma $\mathrm{K}$ concentration.

The mean concentration of $\mathrm{Cl}$ for the plasma from steers ingesting the intermediate levels of $\mathrm{Na}$ and $\mathrm{K}$ was greater than that for the plasma from steers on either the high intakes of $\mathrm{Na}$ or $\mathrm{K}$ or the low levels of $\mathrm{Na}$.

The concentration of $\mathrm{Na}$ and $\mathrm{K}$ in the erythrocytes (difference between whole blood and plasma corrected for packed cell volume) were not significantly affected by the treatments. 


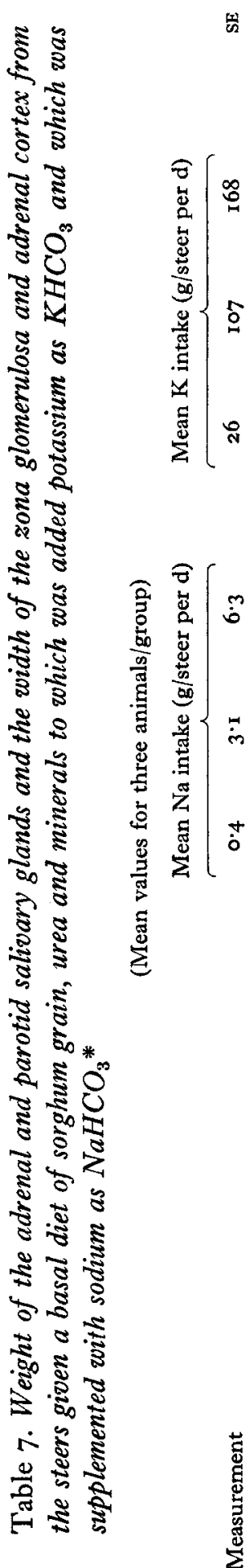

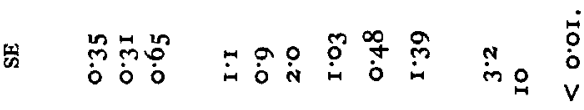

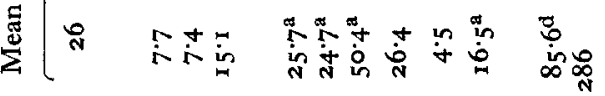


Table 8. Tocopherol content ( $\mathrm{mg} / \mathrm{kg}$ ) of whole sorghum grain and a sample of the sorghumgrain-urea-mineral mixture, with no added $\mathrm{KHCO}_{3}$, that was fed to steers

Sample

Whole grain at day 0 of experiment Whole grain after storage for 6 months Sorghum-grain-urea-mineral mixture*

$$
\alpha \text {-Tocopherol }
$$

$4 \cdot 8$

$3 \cdot 2$

$I \cdot 8$ $\beta-+\gamma-$ Tocopherol

I2 6

$9 \cdot 9$

$3 \cdot 8$

* Sample derived from compositing weekly sub-samples of the grain fed to the steers and stored at $-10^{\circ}$ until analysed 5 months after the start of the experiment.

$N a, K$ concentrations and $p H$ of urine. The mean concentration of $\mathrm{Na}$ for the urine, immediately before slaughter (9Ist day), was significantly $(P<0.0$ I) increased at both levels of $\mathrm{Na}$ supplementation $(7.4,14.5$ and $32.8 \mathrm{mmol} / 1$ for $\mathrm{Na}$ intakes of 0.4 (basal), $3 . \mathrm{I}$ and $6.3 \mathrm{~g} / \mathrm{d}$, respectively), but was not affected by the level of $\mathrm{K}$ in the diet when the effects of all levels of $\mathrm{Na}$ and $\mathrm{K}$ intake were analysed. For the steers given the low-Na (basal) diet, there did appear to be an increase in the $\mathrm{Na}$ concentration for the urine with increasing $\mathrm{K}$ intake, but this trend was not found in the groups receiving the $\mathrm{Na}$ supplements. Similarly, the urinary concentration of $\mathrm{K}$ was not affected by the $\mathrm{Na}$ supplementation, but was significantly $(P<0.0 \mathrm{I})$ increased by the addition of $\mathrm{K}$ to the $\operatorname{diet}(70,129$ and $202 \mathrm{mmol} / 1$ for $\mathrm{K}$ intakes of 26 (basal), 107 and $\mathrm{I} 68 \mathrm{~g} / \mathrm{d}$ respectively). The $\mathrm{pH}$ of the urine from steers given diets with no added $\mathrm{K}$ was significantly $(P<0.0 \mathrm{I})$ lower than that from steers given diets with added $\mathrm{K}(7.5,8.6$ and 8.7 for $\mathrm{K}$ intakes of 26 (basal), 107 and $168 \mathrm{~g} / \mathrm{d}$ respectively).

Adrenal and parotid salivary glands. The weights of the adrenal glands from the steers given the experimental diets (Table 7 ) were considerably greater than the weights of those from the pretreatment group (left gland $4.9 \mathrm{~g}$, right gland $4.5 \mathrm{~g}$, total $9.3 \mathrm{~g}$, SE $1.8 \mathrm{~g}$ ). The weights of the individual left and right glands from steers given the $\mathrm{Na}$ supplements and the sum of their weights was significantly less than those for glands from steers given the basal diet. This effect was also apparent when the weight of the adrenal gland was expressed on a body-weight basis. The widths of the adrenal cortex and the zona glomerulosa (as a percentage of the width of the cortex) were also significantly greater for the adrenals from steers given the basal diet than for those from steers given $\mathrm{Na}$ supplements. However, there was no significant difference between the measurements for adrenals from the two groups of steers given $\mathrm{Na}$ supplements. The addition of $\mathrm{KHCO}_{3}$ to the diet had no significant effect on the absolute adrenal gland measurements. The weights of the parotid salivary glands from steers given the basal diet were greater than those from steers given the high- $K$ $\operatorname{diet}(\mathrm{r} 68 \mathrm{~g} \mathrm{~K}$ ingested $/ \mathrm{d}$ ). When the weight of the parotid salivary gland was expressed on a body-weight basis these differences were no longer apparent.

Tocopherol content of the diet. Tocopherol analysis of a sample of whole grain, taken before the experiment began (Table 8), indicated that the $\alpha$-tocopherol and $\beta-+\gamma-$ tocopherol contents were considerably higher than those of either the whole grain after storage for 6 months or the sorghum-grain-urea-mineral mixture. No $\delta$ tocopherol was detected in any of the samples. Storage of the grain for 6 months 
resulted in a loss of about one-third of the original tocopherol potency, whereas storage for 6 months and combination with the mineral mixture (without added $\mathrm{KHCO}_{3}$ ) resulted in a loss of about two-thirds of the tocopherol potency. As the sorghum-grain-urea-mineral mixture was prepared in batches of about $5 \mathrm{t}$ and not stored for periods longer than I month before it was fed to the steers, the amount of tocopherol ingested was probably similar to that of the whole grain after 6 months' storage.

\section{DISCUSSION}

Assessment of the nutritional adequacy of an essential nutrient in a diet demands the establishment of criteria by which adequacy or deficiency can be defined. In relation to the $\mathrm{Na}$ requirements of growing cattle we chose in our previous study (Morris \& Gartner, I97I) the following criteria: growth rate, food intake, Na and K contents of the saliva and rumen, and adrenal histology, in particular the width of the zona glomerulosa as a percentage of the width of the cortex. When these criteria were applied to the $\mathrm{Na}$ and $\mathrm{K}$ treatments in this experiment, we found that for Na-supplemented steers, those ingesting $3^{\cdot} \mathrm{I} \mathrm{g} \mathrm{Na} / \mathrm{d}$ had food intakes, $\mathrm{Na}$ and $\mathrm{K}$ contents of the saliva and rumen, and adrenal histology which were comparable with those of steers ingesting $6.3 \mathrm{~g} \mathrm{Na} / \mathrm{d}$. However, the mean growth rate for steers ingesting $3 \cdot \mathrm{I} \mathrm{g} \mathrm{Na} / \mathrm{d}$ was slightly less than that for steers ingesting $6 \cdot 3 \mathrm{~g} \mathrm{Na} / \mathrm{d}$, but the difference was not significant, and the mean growth rate for Na-supplemented steers was greater $(P<$ 0.06) than that for steers given the basal diet. It appears, therefore, that a net intake of $3^{\cdot}$ I $\mathrm{g} \mathrm{Na} / \mathrm{d}$ was adequate for growth. The addition of $\mathrm{KHCO}_{3}$ to the diet resulted in a significant depression of growth rate and did not appear to increase the requirement for Na.

The changes in the composition of the saliva associated with the two rates of $\mathrm{Na}$ supplementation were similar to those reported in a previous experiment (Morris \& Gartner, $197 \mathrm{I}$ ) in which steers were given an all-grain diet with no added $\mathrm{KHCO}_{3}$. The $\mathrm{Na}: \mathrm{K}$ ratio for the saliva was not apparently affected by the amount of $\mathrm{K}$ in the diet, which is in agreement with Scott's $\left(19^{6} 7\right)$ report that $K$ supplementation of the diet does not affect the $\mathrm{Na}$ content of saliva.

The positive relationship between the $\mathrm{Na}$ concentration for the rumen fluid and the rate of $\mathrm{Na}$ supplementation and the negative relationship between the $\mathrm{K}$ concentration of the rumen fluid and the rate of Na supplementation were similar to those reported by Morris \& Gartner (I97I). The addition of $\mathrm{K}$ to the basal diet significantly increased the $\mathrm{K}$ concentration of rumen fluid and decreased the $\mathrm{Na}$ concentration, in agreement with the report of Scott $(1967)$ that infusions of $\mathrm{K}$ salts into the rumen increased the concentration of $\mathrm{K}$ in the rumen fluid but decreased the $\mathrm{Na}$ concentration.

The widths of the adrenal cortex and the zona glomerulosa (as a percentage of the width of the cortex), for steers given the basal diet, were greater than those for steers ingesting $3 \cdot \mathrm{I}$ or more $\mathrm{g} \mathrm{Na} / \mathrm{d}$ and were similar to those previously reported by Morris \& Gartner (I97 I). Adrenal histology was not affected by the amount of $\mathrm{K}$ in the diet.

Von Bunge (1873) first drew attention to the relatively high content of $\mathrm{K}$ 
relative to $\mathrm{Na}$ in the diet of herbivorous animals, and suggested that their desire to balance the $\mathrm{Na}: \mathrm{K}$ ratio in the diet may account for their general avid consumption of $\mathrm{NaCl}$. In short-term experiments, the oral and intravenous administration of $\mathrm{KCl}$ to sheep (Dewhurst, Harrison \& Keynes, I968; Scott, I969) and intravenous administration of $\mathrm{KCl}$ to cattle (Anderson \& Pickering, 1962) have been shown to produce an immediate natriuresis. However, from $8 \mathrm{~d}$ balance studies with dairy cows Kemp (1964) suggested that when $\mathrm{KHCO}_{3}$ is added to the diet, urinary $\mathrm{Na}$ excretion is only temporarily increased, whereas faecal $\mathrm{Na}$ excretion may be reduced. St Omer \& Roberts (1967) have reported results from a balance trial in which urinary and faecal excretion of $\mathrm{Na}$ by heifers is not affected when the daily intake of $\mathrm{K}$ is increased from 6.26 to $42 \cdot 6 \mathrm{~g}$. As our measurements did not include urine volume, no firm conclusions about the effect of $\mathrm{K}$ on urinary $\mathrm{Na}$ loss can be made from our results. However, as the interaction between dietary levels of $\mathrm{Na}$ and $\mathrm{K}$ had no significant effect on criteria such as the saliva $\mathrm{Na}: \mathrm{K}$ ratio, it did not appear that $\mathrm{K}$ supplements exacerbated $\mathrm{Na}$ deficiency. Therefore, apparently either the $\mathrm{K}$ supplements did not cause a marked diuresis and the concentration of urine $\mathrm{Na}$ was not significantly affected by $\mathrm{K}$ levels, or a natriuresis was compensated by reduced losses by other pathways e.g. faecal. Therefore, our results support those of Kemp (1964) and St Omer \& Roberts (1967) and suggest that over a prolonged period cattle can fully compensate in their $\mathrm{Na}$ metabolism for a high intake of $\mathrm{K}$. Therefore, the Na requirement of steers for growth is apparently not affected by the $\mathrm{K}$ content of the diet up to an intake of $168 \mathrm{~g} \mathrm{~K} / \mathrm{d}$.

The positive relationship between urine $\mathrm{pH}$ and the $\mathrm{K}$ content of the diet was probably a consequence of the greater urinary excretion of basic ions by steers receiving diets containing added $\mathrm{KHCO}_{3}$. Dewhurst et al. (1968) found that about $90 \%$ of the dietary $\mathrm{K}$ and about $80 \%$ of a $\mathrm{K}$ load $(\mathrm{KCl}$ administered into the rumen) was excreted in the urine of sheep, and that urine volume increased after $\mathrm{KCl}$ administration.

Matrone, Ramsey \& Wise (I959) demonstrated that the addition of bicarbonates of $\mathrm{Na}$ and $\mathrm{K}$ to an all-concentrate diet increased the food intake and growth rate of lambs. The effect of the addition of these salts and other buffers to high-concentrate diets on the performance of growing or lactating cattle and sheep has subsequently been reported by a number of workers. Wise, Blumer, Matrone \& Barrick (I96I) found that the addition of $\mathrm{NaHCO}_{3}$ and $\mathrm{KHCO}_{3}$ (40 and $70 \mathrm{~g} / \mathrm{kg}$ respectively) to an allconcentrate diet reduced food intake and body-weight gain of beef steers. Similarly, Nicholson, Cunningham \& Friend (1963) reported that in one trial the rate of bodyweight gain was not increased compared with that of control animals when $30 \mathrm{~g}$ $\mathrm{NaHCO}_{3}+10 \mathrm{~g} \mathrm{KHCO}_{3}+20 \mathrm{~g}$ ground limestone $/ \mathrm{kg}$ was added to an all-concentrate diet, but, in another trial, the addition of $30 \mathrm{~g} \mathrm{NaHCO} / \mathrm{kg}$ diet, alone, increased food intake. These workers also reported (Nicholson \& Cunningham, 196r; Nicholson, Cunningham \& Friend, I962) that the addition of $\mathrm{NaHCO}_{3}$ to mixed and all-concentrate diets does not result in an increased rate of body-weight gain. Woolfitt, Howell \& Bell (1964) reported an increase in the efficiency of food conversion in lambs when $20 \mathrm{~g} \mathrm{NaHCO}_{3} / \mathrm{kg}$ was added to a high-concentrate diet but not when $20 \mathrm{~g}$ $\mathrm{NaHCO}_{3}+20 \mathrm{~g}$ sodium citrate $/ \mathrm{kg}$ were added. However, Packett \& Butcher (I963) 
found a marked increase in the growth rate of lambs given a cottonseed-hull-concentrate diet when $3 \circ \mathrm{g} \mathrm{Na}$ citrate $/ \mathrm{kg}$ was added to the diet.

We found a higher incidence of bloat in steers given the diet with added $\mathrm{KHCO}_{3}$ than in those given the basal diet, which agreed with findings of Emery \& Brown (I96I). They found that bloat in dairy cows given a high-concentrate diet is apparently aggravated by the addition of $\mathrm{NaHCO}_{3}$ or $\mathrm{KHCO}_{3}(0 \cdot 45 \mathrm{~kg} / \mathrm{cow}$ per d) to the diet. They suggested that bloat may contribute to the lower food intake of cows given diets containing bicarbonate, compared to that of cows given the control diet.

The mean concentration of $\mathrm{Na}$ found in the plasma of all steers in this experiment, irrespective of $\mathrm{Na}$ intake, was less than that reported by Morris \& Gartner (1971). In this previous experiment, no consistent effect of dietary $\mathrm{Na}$ restriction on plasma $\mathrm{Na}$ was found, but in this experiment an effect was found. The difference in the response of the steers in the two experiments may have been due in part to age. Morris \& Murphy (1972) showed a marked decrease in plasma $\mathrm{Na}$ and increase in $\mathrm{K}$ for young calves given a low- $\mathrm{Na}$ diet.

The concentration of $\alpha$-tocopherol for the whole grain before milling $(4.8 \mathrm{mg} / \mathrm{kg})$ was considerably less than the value estimated for the requirement of young calves by the (US) National Research Council ( 1970 ) ( $15-60 \mathrm{mg} \mathrm{DL}-\alpha$-tocopherol/kg diet). As the $\alpha$-tocopherol concentration of the diet eaten by our steers when they were not receiving an $\alpha$-tocopherol supplement was in the range of $1.8-4.8 \mathrm{mg} / \mathrm{kg}$ diet, it would appear that for older cattle given an all-grain diet, growth rate was not restricted by an $\alpha$-tocopherol concentration of $4.8 \mathrm{mg} / \mathrm{kg}$ diet.

The authors wish to thank the Australian Meat Research Committee for financial assistance under Project DAQ25; the Southern Electric Authority, Tennyson Power House, for donation of the demineralized water; Dr S. R. V. Nobile, Roche Laboratories, Dee Why, New South Wales for tocopherol analysis; Miss Patricia M. Pepper for statistical analyses; $\mathrm{Mr} \mathrm{K}$. Schultz for preparation of the histological material; $\mathrm{Mr}$ M. J. Radel for care of the experimental animals and Miss J. M. Dalby, Mr J. Connel and $\mathrm{Mr} \mathrm{D}$. N. Utting for technical assistance.

\section{REFERENCES}

Agricultural Research Council (1965). The Nutrient Requirements of Farm Livestock No. 2, Ruminants. London: Agricultural Research Council.

Anderson, R. S. \& Pickering, E. C. (1962). Y. Physiol., Lond. 164, 180.

Dewhurst, J. K., Harrison, F. A. \& Keynes, R. D. (1968). F. Physiol., Lond. 195, 609.

Emery, R. S. \& Brown, L. D. (196r). F. Dairy Sci. 44, I899.

Kemp, A. (1964). Neth. F. agric. Sci. 12, 263.

Matrone, G., Ramsey, H. A. \& Wise, G. H. (1959). Proc. Soc. exp. Biol. Med. roo, 8.

Morris, J. G. \& Gartner, R. J. W. (1971). Br. F. Nutr. 25, 191.

Morris, J. G. \& Murphy, G. W. (1972). F. agric. Sci., Camb. 78, 105.

Morris, J. G. \& Pepper, P. M. (1969). 7. agric. Sci., Camb. 73, 4I.

National Research Council (1970). Publs natn. Res. Coun., Wash. no. 1754.

Nicholson, J. W. G. \& Cunningham, H. M. (I96I). Can. F. Anim. Sci. 4I, 134.

Nicholson, J. W. G., Cunningham, H. M. \& Friend, D. W. (1962). Can. F. Anim. Sci. 42, 75.

Nicholson, J. W. G., Cunningham, H. M. \& Friend, D. W. (r963). F. Anim. Sci. 22, 368.

Nobile, S. R. V. (1963). Australas. F. Pharm. 44, 26.

Packett, L. V. \& Butcher, G. A. (1963). F. Anim. Sci. 22, I 100. 
Scott, D. (1967). Q. Il exp. Physiol. 52, 382.

Scott, D. (1969). Q. $.7 l$ exp. Physiol. 54, 25.

St Omer, V. V. E. \& Roberts, W. K. (1967). Can. F. Anim. Sci. 47, 39.

Von Bunge, G. (1873). Z. Biol. 9, r04.

Wise, M. B., Blumer, T. N., Matrone, G. \& Barrick, E. R. (I96r). F. Anim. Sci. 20, 56r.

Woolfitt, W. C., Howell, W. D. \& Bell, J. M. (1964). Can. Y. Anim. Sci. 44, I79. 